\title{
Student's Statistical Literacy skills Based on the Reflective and Impulsive Cognitive Styles
}

\begin{abstract}
Titin Masfingatin ${ }^{1}$, Edy Suprapto ${ }^{2}$
${ }^{1,2}$ Universitas PGRI Madiun, Indonesia

Article Info

Submitted : 25-07-2020

Revised : 13-09-2020

Accepted : 16-10-2020

Published : $30-10-2020$

*Correspondence:

titin.mathedu@unipma.ac.id

\section{Abstract}

This study aimed to describe students' statistical literacy skills based on their reflective-impulsive cognitive style. This study employed descriptive exploratory research with the qualitative approach. The data collecting techniques used were tests, interviews, and field notes. The data analysis techniques employed were data reduction, data presentation, and drawing conclusions. This study discovered that students' reflective and impulsive cognitive styles influence their statistical literacy skills such as the ability to construct or interpret information or statistical data, understand statistical concepts, and represent the statistical data in a different form. Students with the reflective cognitive style were different from students with the impulsive cognitive style on statistical literacy skills, especially in evaluating statistical information or arguments. Students with the reflective cognitive style tended to be more critical in evaluating statistical information or arguments by providing arguments based on the results of analytical calculations. Students with the impulsive cognitive style used analytical processes in drawing statistical conclusions. Students with the impulsive cognitive style lacked cognitive maturity and tended to use processes holistically rather than analytically in drawing statistical conclusions.
\end{abstract}

Keywords: Cognitive Style; Statistical Literacy; Reflective-Impulsive.

\section{Introduction}

Students' statistical ability is needed to face the digital era in the 21 st-century. The pervasive role of statistics in the digital society asks for the ability to deal with data and chance, encompassing big ideas such as variability, sampling, error, prediction, and the distinction between signal and noise. Related aspects are data collection and data displays (graphs, frequency tables, and pie charts) (Gravemeijer, Stephan, Julie, Lin, \& Ohtani, 2017). The statistics material that students must master is the measurement, data collection, variables and covariance, reading and interpreting data, as well as graphs and charts (Gravemeijer et al., 2017; Hoyles, C., Wolf, A., Kent, P., \& Molyneux-Hodgson, 2002; Hoyles, Celia \& Noss, Richard \& Kent, Phillip \& Bakker, 2010). A good understanding of statistical concepts supported by adequate mathematical skills is not sufficient without the ability to read and interpret statistical data. This ability is known as statistical literacy skills.

Statistical literacy requires students to understand and interpret the statistical concepts they have learned. It means that students must know the purpose of the statistical concepts rather than just solving statistical questions and the implications of the conclusions obtained from statistical information. Students should not only consider that statistics is merely a collection of data.

Students must master statistical literacy skills well to compete in the 21 st-century. Being the future generation of our community, students need to acquire statistical knowledge and its applications to prepare for their future careers as well as to make more rational decisions in daily 
endeavors (Wing-yan, 2013). Students who have statistical literacy skills will be able to think critically about the information or data they read. This ability is also necessary for students when they are required to learn independently. Online learning requires students to understand and interpret statistical data to carry out evaluations to master further statistics material.

Statistical literacy is a person's ability to understand; interpret; and represent data, either in tables or graphs (Hafiyusholeh, 2015). A similar opinion is conveyed by (Ben-zvi \&Garfield, 2014; Gal, 2002) that statistical literacy skills include students' ability to interpret information related to statistical data, critically evaluate (based on the results of in-depth analysis) the statistical information, and communicate statistical information and message. The statistical literacy skills referred to in this study was the ability to interpret information or arguments related to statistical data; understand statistical concepts, vocabulary, and symbols; critically evaluate the statistical information or arguments related to data (based on the results of in-depth analysis); and present the results of statistical data processing. Therefore, statistical literacy skills are very important for students so that they can solve problems related to statistics.

Statistical literacy skills need to be developed. Several studies show that students' statistical literacy skills are low and unsatisfactory (Maryati \& Priatna, 2018; Mulya, Nurlaelah, \& Prabawanto, 2018). The results of the study by (Nishfani, Kusmanto, \& Akbar, 2017) show that most students are not familiar with statistical literacy questions that use narrative to describe statistical problems. This is also supported by preliminary observations made at SMP Wonoasri Madiun that students have not been able to solve statistical questions. Most students could not understand the information contained in the questions presented in the form of a presentation of statistical data, both in tables and graphs.

Early mathematical abilities support students' statistical literacy skills (Hartuti \& Widyasari, 2016; Takaria \& Talakua, 2018). (Gal, 2002; Sharma, 2017) state that statistical literacy is based on joint activation of five interrelated knowledge (literacy, statistics, mathematics, context, and critical). Statistical literacy is needed when students are dealing with information presented in the form of statistical data. Students must be able to interpret the meaning of the information and evaluate the information critically as a basis for drawing conclusions. Especially for junior high school students, statistical literacy skills are needed when they want to study statistics at the next level of education. Statistical literacy includes basic and important skills that may be used in understanding statistical information or research results (Ben-zvi \& Garfield, 2014; Hafiyusholeh, 2015). When students compile a study related to statistics, they must understand and interpret the statistical concepts properly. This means that students must have statistical literacy skills.

On the other hand, students as the future generation of modern society need to acquire statistical knowledge and its applications to prepare for their future to make more rational decisions in everyday life (Wing-yan, 2013). Statistical literacy is the ability to interpret statistical data into information and knowledge and then apply it in everyday life. Statistical literacy is important for students because, in the end, they will face their role as producers or consumers of data (Hafiyusholeh, 2015). As the data producers, students must understand how to present data so that the data presented can be easy to read and can be understood by others. As the data consumers, students are required to read data as well as to understand the meaning contained in the data, both implied and literal.

Students' characteristics differ from one another. This difference also occurs when they receive, process, and present information. This kind of difference is called cognitive style. The 
cognitive style will continue to be attached to a high level of consistency so that it affects student behavior and activities, both directly and indirectly (Suryanti, 2014). Students can be differentiated into reflective and impulsive styles. The student with the impulsive cognitive style responds (answer) briefly and quickly by choosing what they think is right while the student with the reflective cognitive style considers the answers before responding and carefully conceptualize each alternative (Rozencwajg \& Corroyer, 2005). The different characteristics of the two types of students' cognitive styles may affect their statistical literacy skills. Most students with the reflective cognitive style are better at completing tasks that require analysis whereas the students with the impulsive cognitive style are better at completing tasks that require holistic or global thinking.

Statistical literacy has been a topic of research in recent years. Among them is research conducted by (Maryati \& Priatna, 2018; Mulya et al., 2018; Nishfani et al., 2017). Research on statistical literacy skills and cognitive styles has been carried out by (Amalia, Wildani, \& Rifa'i, 2020). which discovered that the statistical literacy skills of students with field independent (FI) cognitive style are different from the field-dependent (FD) students. The reflective-impulsive cognitive style is a cognitive style that shows the tempo or speed of thinking while the FI-FD cognitive style differentiates more about how a person's psychological state and how a person interacts with their environment (Azhil, Ernawati, \& Lutfianto, 2017). Reflective-impulsive cognitive style is a person's way of thinking based on tempo, namely how much time a student takes to respond to information received. Research by (Nurdianasari, Rochmad, \& Hartono, 2015) examines the mathematical literacy abilities of students with the reflective-impulsive cognitive style. This study focuses on the literacy abilities of students with the reflectiveimpulsive cognitive style related to statistical data which is better known as statistical literacy. Statistical literacy skills are the initial stage of mastering statistical material, especially for junior high school students. This research needs to be done considering the importance of statistical literacy skills in mathematics learning (Mulya et al., 2018). Students will use the statistical concepts not only within the school but also in a wider environment.

\section{The Research Methods}

This study employed descriptive exploratory with the qualitative approach. The research subjects were the seventh-grade students of SMP Negeri 1 Wonoasri in the 2018/2019 academic year. The subjects were based on the results of the Matching Familiar Figure Test (MFFT) designed by Warli (2010) and data on solving statistical questions. The MFFT test was used to classify students into reflective and impulsive cognitive styles. The results of the MFFT test showed that students' tendencies were related to their thinking styles when facing statistical questions. The instrument used to reveal students' statistical literacy skills was in the form of statistical questions that contain complex problems related to the context of everyday life (Callingham \& Watson, 2017). Figure 1 displays the instrument used in this study. 
The result of the daily test of students in class VIIC is presented in the following table:

\begin{tabular}{|c|c|}
\hline Score & Number of Students \\
\hline 5 & 3 \\
\hline 6 & 4 \\
\hline 7 & 10 \\
\hline 8 & 7 \\
\hline 9 & 4 \\
\hline 10 & 2 \\
\hline
\end{tabular}

Based on the data, answer the following questions:

a. The class president said that the average score of the class was 7 since many students got that score. Is that statement correct? Explain your answer!

$b$. What are the median and mode of data?

c. A student is said to pass the test if he gets a score of more than or equal to 6. What percentage of students who did not pass?

d. Present the data on the question in another form!

Figure 1. The Statistical Literacy Questions (As'ari, Tohir, Valentino, Imron, \& Taufiq, 2017)

First, students were given the MFFT test to determine whether they have a reflective or impulsive cognitive style. Second, the students were asked to answer the statistical questions. These two tests were conducted so that data of students' thinking styles and their literacy skills can be obtained at the same time as a consideration in determining the research subjects. The results of the analysis of the test were then used to determine the research subjects which consisted of 2 subjects, namely 1 subject with the reflective cognitive style and 1 subject with the impulsive cognitive style. Besides, the subjects were also decided based on the ability to solve statistical questions. The analysis of data from the written test results and interviews was carried out by reducing data, presenting data, and drawing conclusions. Figure 2 shows the process of analyzing the written test data and interviews.

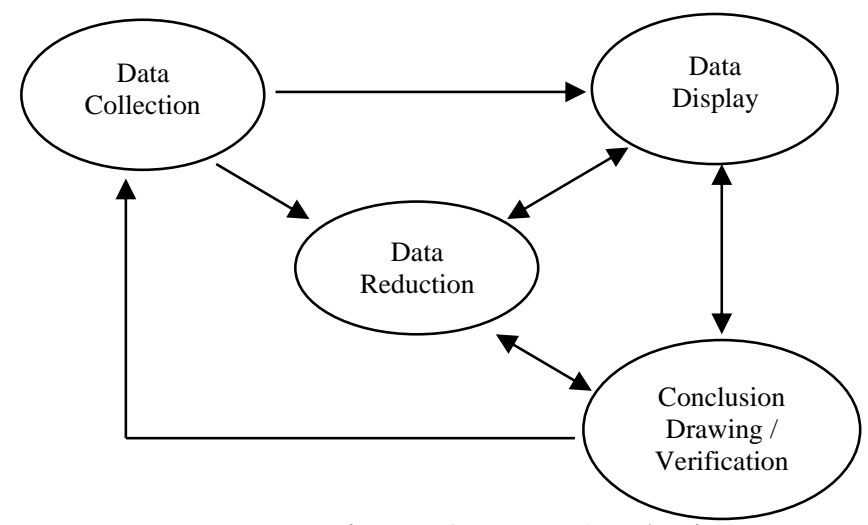

Figure 2. Data Analysis

(Miles \& Huberman, 2007) 


\section{The Results of the Research and the Discussion}

The analysis of research data was carried out on the results of the written test and interviews. The data analysis was carried out on students with reflective and impulsive cognitive styles respectively. The student with the reflective cognitive style was able to interpret the data in the table and connected them to previous knowledge. Based on the questions, the student was able to understand the data presented in the table. He wrote that the mean or average value was equal to each value multiplied by the frequency and then divided by the number of frequencies. Figure 3 shows his answer.

\begin{tabular}{|c|c|}
\hline 17) Mean/rilal rata-rata $=\frac{(5 \times 3)+(6 \times 4)+(7 \times 10)+1}{3+4+10+7+4}$ & $27+(9 \times 4)+(6)$ \\
\hline$\therefore 15+2 A+70+56+3 b+20$ & $=221=736$ \\
\hline Berolyataan ketua kelas terbesut benac. 30 & 30 \\
\hline
\end{tabular}

Figure 3. The answer to question (a) by a Student with the reflective Cognitive Style

The results of interviews related to problem-solving (a) by the student with the reflective cognitive style can be seen below:

$P(27):$ "How did you find the mean value?"

R2.27: "5 multiplied by 3, 6 multiplied by 4, the result of the multiplication of frequencies is divided by the number of frequencies."

$P(28)$ : "So, how many frequencies??"

R2.28: "30."

$P(29):$ "What about your answer?"

R2.29: "7,36."

$P(30):$ "Did you round-up the value?"

R2.30: "Yes, I did."

$P(32):$ "What can you infer from the class president's statement?"

R2.32: "Can be right and can be wrong."

$P(33):$ "How, can you elaborate your answer?"

R2.33: "It was correct if it was rounded-up and it was wrong if it was not rounded-up."

$P(34):$ "If the statement was wrong, then what should be the answer?"

R2.34: "7,36

The result of the interview showed that the student was able to understand the concept that the average score is the total value divided by the frequency, the median is the middle value, and the mode is the value that often occurs. This was also shown in the written results. Also, the student with the reflective cognitive style was able to evaluate based on the arguments obtained from the calculation results by constructing solutions that can be applied to the average score formula. This indicated that the student with the reflective cognitive style was able to critically evaluate statistical information.

The student transformed the group data into single data by rewriting the scores from smallest to largest to determine the median. He eliminated the pairs of large and small values in order until the last two values were found. Figure 4 is a written result of the student's work. 


b.). $58866667 \times 7 \quad$ Median $=\frac{7+7}{2}=\frac{14}{2}=7$
$7 \pi 77777888$
s.88 $899991010 \quad$ Modus $=7$

\section{Figure 4. The Answer to Question (b) by Students with Reflective Cognitive Style}

$P(24):$ "Next, how did you determine the median?"

R2.24: "First, I arranged the numbers. Then, I eliminated the smallest and largest values to find the last two values."

The student was able to interpret the data presented in tabular form. He was able to explain that three students failed because students who scored below 6 were those who got a score of 5 which had a frequency of 3. In the questions, he was asked to determine the percentage of students who did not pass. The student with the reflective cognitive style can perform the calculations to determine the percentage by dividing the students who did not pass and the number of frequencies which then the result was multiplied by one hundred percent.

$P(5):$ "How did you solve the question c?"

R2.5: "The score of students who passed was equal to or more than 6. So, if the score was lower than 6 could not pass."

$P(6):$ "What was the point of question $c$ ?"

R2.6: "The percentage of students who did not pass."

$P(7)$ : "How did you find the answer?"

R2.7: "Students who did not pass were added up."

$P(8)$ : "How many students who did not pass?"

R2.8: "There were 3. Those who scored below 5 "

$P(9):$ "Why 5? Explain your answer!"

R2.9: "Because students who scored 6 or more."

$P(10):$ "Then, how did you calculate the percentage?"

R2.10: "The number of students who did not pass was divided by the total frequency and then multiplied by 100."

$P(11):$ "And the result?"

R2.11: "10\%.

The answer of a student with the reflective cognitive style on point (c) can be seen in Figure 5.

c.) Peresentasi siswa yana tidak lulus
$\frac{3}{30} \times 100=\frac{30}{3}=10 \%$

Figure 5. The Answer to Question (c) by a Student with the Reflective Cognitive Style

At point (d), the student was asked to transform the data in the table into another form. The students with the reflective cognitive style were able to transform the data into a bar chart. The chart was accompanied by information on the total number of students in the vertical axis and scores on the horizontal axis. Figure 6 displays the result of the student's work. 


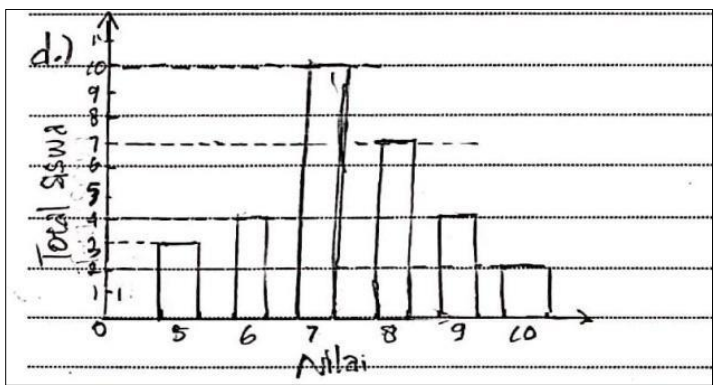

Figure 6. The Answer to Question (d) by a Student with the Reflective Cognitive Style

Another thing that can be analyzed was that the student with the reflective cognitive style performed the calculations in great detail. It was shown in determining the average value where he wrote down the scores of the students and the number of students in parentheses and then added them up (Figure 3). The student with the reflective cognitive style worked the analytics in determining the median. He sorted the data in the table into a single data based on the frequency. To make the data visible, he crossed out the pairs of values from the left and right sides so that two middle values were obtained. The two values were added up and the result was divided by two to obtain the median (Figure 4).

The student with the impulsive cognitive style determined the average value by multiplying each value by its frequency, adding it up, and dividing the result by the number of frequencies. Meanwhile, to determine the median, he immediately wrote that the median was equal to 7 . Figure 7 shows the results of the questions (a) and (b) by students with the impulsive cognitive style.

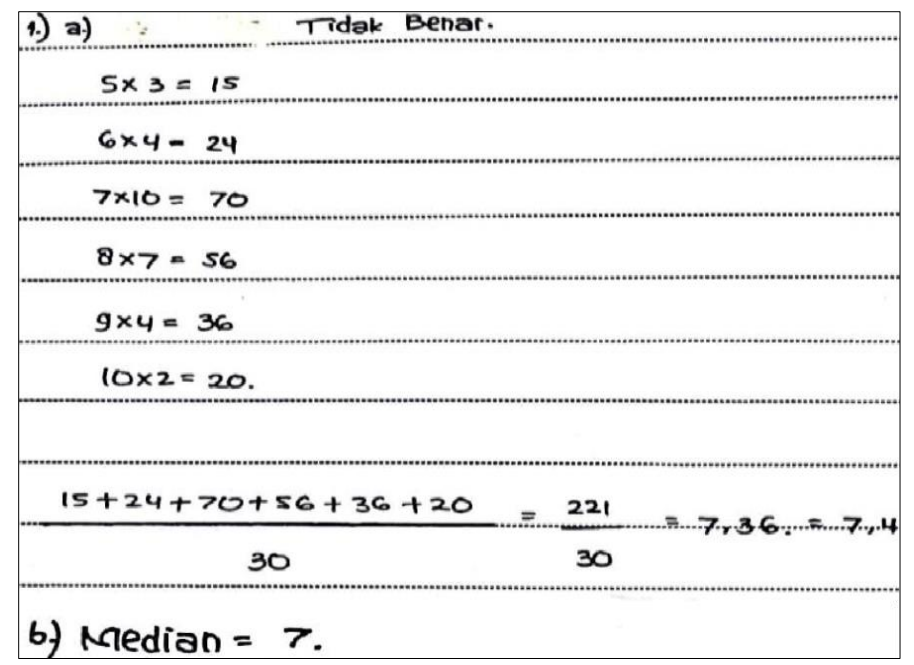

Figure 7. The Answer to Questions (a) and (b) by a Student with the Impulsive Cognitive Style

$P$ (29): "How did you find the average score?"

I2.29: "First, I added up the data, 5 multiplied by 3 plus 6 multiplied by 4 plus 7 multiplied by 10 plus 8 multiplied by 7 plus 9 multiplied by 4 plus 10 multiplied by 2 divided by the numbers of data so that 221 divided by 30 equals 7, 36 became 7.4 if it is rounded.

$P$ (30): "What can you conclude from the statement of point a?"

I2.30: "Wrong statement."

P (31): "Why was it wrong? Explain the reason!" 
I2.31: "Because it was stated that the average score of class VIII C's science exam was 7 whereas after calculating the result, it was 7.4."

The answer to point (b) by a student with the impulsive cognitive style is displayed in Figure 8 .

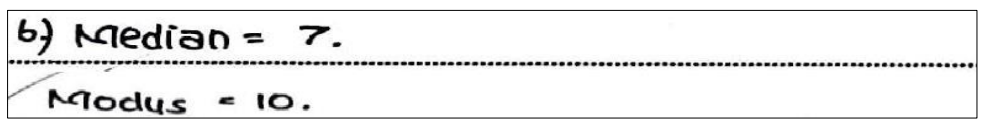

\section{Figure 8. The Answer to Question (b) by a Student with the Impulsive Cognitive Style}

In determining the median, the student with the impulsive cognitive style was able to explain how the median is defined.

$P(16):$ "What about point $b$ ?"

I2.16: "I determined the mean value."

$P(26):$ "How?"

I2.26: "If the number is odd I can directly find the mean. If the number is even, I determined the 2 numbers in the middle. Based on the table, the frequency is 30, so the answer is the 15th number"

$P(27):$ "Why 15?"

I2.27: "Because 30 divided by 2 equals 15 and the 15th value is 7.

The results showed that the student with the impulsive cognitive style was able to understand the concept of the median. He was also able to explain how to determine the median of even and odd data. However, he was unable to carry out the calculation process correctly. Also, he was able to interpret the data in the table and explain how to determine the median. The student with the impulsive cognitive style wrote that the mode of the data was 7 . He explained that the mode was a value that often appears.

$P(18):$ "Then, what is the meaning of mode?"

I2.18: "The most frequently appears value."

$P(19):$ "What is the frequently appear value in the data?"

I2.19: "10."

$P(20):$ "Why 10? Can you explain it?

I2.20: "Sorry, I mean 7."

$P(21):$ "So, your answer was wrong?"

I2.21: "I think yes.

In determining the mode, the student understood the concept of mode. He was able able to determine the mode of the data in the table, thus he can interpret the statistical data. At point (c), the student completed the answer sheet as can be seen in Figure 9.

c) $\begin{aligned} \frac{3}{38} \times 100 & =\frac{30}{3} \\ & =10 \%\end{aligned}$

Figure 9. The Answer to Question (c) by a Student with the impulsive Cognitive Style 
The results of the interview related to question (c) are as follows:

I2.6: "For point c, the frequency is 3."

$P$ (7): "Where did you get 3?"

I2.7: "From the least value."

$P(8):$ "What was the smallest score in the question?"

I2.8: "Value greater than or equal to 6."

$P$ (9): "So which value to use?"

I2.9: "Score below 6."

$P(10):$ "What was the value below 6."

I2.10: "5 ma'am."

$P(11):$ "Then what was the frequency of value 5?"

I2.11: "3."

$P$ (12): "After that, how did you solve the question c."

I2.12: "The 3 frequency was divided by the number of students."

P (13): "After that, what are the next steps?"

I2.13: "Multiplied by 100."

The student with the impulsive cognitive style determined the percentage using prior knowledge. Based on the results of the interview, it can be seen that the student was unable to provide logical arguments. The answers given were unreasonable, so it is necessary to provide scaffolding or questions that lead him to the solution (P (10), P (11)).

He the data into a bar chart. He completed the chart by writing the frequency on the vertical side and the values on the horizontal side. However, on the vertical line, he did not write the same scale. Figure 10 is the answer to question (d).

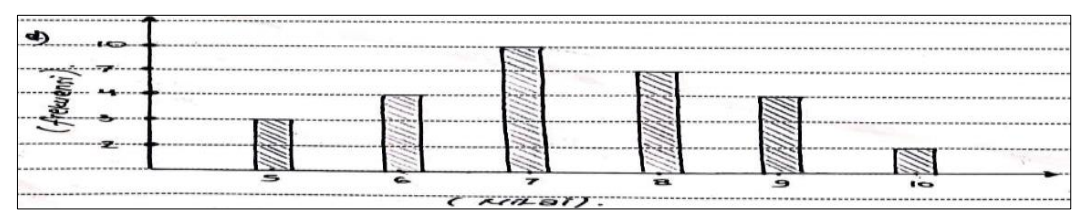

\section{Figure 10. The Answer to Question (d) by a Students with the impulsive Cognitive Style}

Besides the results of the test and interview, the results of the observations on the working duration of the two subjects were also noted. The results of the observation showed that there was a difference in the duration of the problem solving between the students. The student with the reflective cognitive style worked on the questions within 28 minutes while the student with the impulsive cognitive style worked on the same questions within 15 minutes. The student with the reflective cognitive style needed a relatively long time.

The indicators of statistical literacy skills consist of the ability to interpret or argue related to statistical data, understand concepts, understand the vocabulary and symbols of statistical information, critically evaluate statistical information or arguments related to statistical data (based on in-depth analysis results), represent the data into other forms, communicate the data processing, and to present the results of data processing.

Based on the results of the research, each student's statistical literacy skills can be identified. The student with the reflective cognitive style was able to interpret the statistical data. The student 
with the reflective cognitive style was able to interpret the data in the table and then grouped them to obtain the mean, median, and mode. The student with the impulsive cognitive style, on the first indicator, showed an ability to interpret statistical data and determined the mean, median, or mode. The results showed that there was no difference in the ability to interpret statistical data between the reflective and impulsive cognitive styles. This is in line with (Shabani, Ramazani, \& Alipoor, 2017; Sulisawati, Lutfiyah, \& Murtinasari, 2019) that students with the reflective and impulsive cognitive styles do not differ significantly in understanding a problem.

In the second indicator, namely understanding statistical concepts, students with the reflective and impulsive cognitive style were able to understand the concepts of mean, median, and mode. They were able to explain the definition of mean, median, and mode in their own words. This is in line with (Shabani et al., 2017) that students with reflective and impulsive cognitive styles do not differ significantly in understanding a problem. After they were able to understand the concept of mean, median, and mode, they determined each value. They were able to communicate the data processing process, namely the process of determining the mean, median, and mode. In the data processing, the student with the reflective cognitive style was more careful and thorough.

The third indicator was evaluating information or arguments critically. This indicator required the students to provide answers accompanied by deep consideration and not only random answers. The student with the reflective cognitive style evaluated the statistical information more critically than the student with the impulsive cognitive style. The student with the reflective cognitive style provided answers based on the results of analytical calculations so that the arguments given were logical. In contrast, the student with the impulsive cognitive style could not evaluate information critically. When answering questions during the interview, the student with the impulsive cognitive style answered spontaneously without considering the answers. This is relevant to the result of research by (Aprilia, Sunardi, \& Trapsilasiwi, 2017) which state that students with the impulsive cognitive style answered without analyzing the existing data. They tend to think globally and lack detail. These results also reinforce the results of research by(Rozencwajg \& Corroyer, 2005) that students with the reflective cognitive style tend to think analytically and cognitively while students with the impulsive cognitive style tend to think holistically or globally.

Students with a reflective cognitive style can evaluate information critically. The ability to evaluate information critically is related to their ability to think critically. The results of this study are in line with (Rahayu \& Winarso, 2018) that students with a reflective cognitive style have better critical-thinking skills than students with the impulsive cognitive style. However, these results contradict the research results by (Rochika \& Cintamulya, 2017) that reflective and impulsive cognitive styles do not differ in critical-thinking abilities. This research (Rochika \& Cintamulya, 2017) focuses on the critical-thinking ability of students in biology subject with the Mean End Analysis (MEA) model while this study was focused on students' ability in statistical literacy.

The fourth indicator of statistical literacy is the ability to represent statistical data in different forms. Students with the reflective and impulsive cognitive style were able to represent data in tables into bar charts. This result is in line with (Nurdianasari et al., 2015) that students with reflective and impulsive cognitive styles have the same ability in the aspects of representing data and using mathematical tools in mathematical literacy. However, these results are contradictory with the research by (Mulya et al., 2018). which discovered that students are good 
at understanding the data but they have a limited understanding of the data presentation concept. They face difficulty in using the principle of presenting the data into the pie chart. They can understand the data well, but unable to understand the concept of presenting the data well. In this study, students presented the data in the form of tables into a bar chart while in Mulya's research, students represented the data into a pie chart. This difference differs this research from Mulya's research.

Another thing that can be observed was that in the presentation, the student with the reflective cognitive style made a much more detailed bar chart by making the same scale in addition to writing the size of the frequency. Meanwhile, the student with the impulsive cognitive style only wrote the frequency. This shows that the student with the reflective cognitive style represented statistical data analytically compared to the student with the impulsive cognitive style. The student with the impulsive cognitive style only presented an outline of the bar chart by writing down the frequency regardless of whether the scales were the same or not.

The results of this study indicated the tendency of students with the reflective cognitive style to work analytically. They were able to control and implement the knowledge properly. It was in contrast to the student with the impulsive cognitive style who tend to work holistically or globally and showed less analytical completion processes. The student with the impulsive cognitive style was cognitively less mature so they need scaffolding in responding to answers. These results reinforce the opinion of (Nurdianasari et al., 2015; Rozencwajg \& Corroyer, 2005) that student with the impulsive cognitive style is not cognitively mature. The tendency to think analytically supports the research by (Sulisawati et al., 2019) that students with the reflective cognitive style make fewer mistakes in problem-solving compared to a student with the impulsive cognitive style. The student with the reflective cognitive style only makes mistakes because of careless calculations while the student with the impulsive cognitive style makes mistakes in determining problem-solving strategies.

The student with the reflective cognitive style had the same statistical literacy skills as the student with the impulsive cognitive style, namely the ability to interpret statistical information or data, understand statistical concepts, and represent statistical data in different forms. This strengthens the results of research by (Amimah \& Fitriyani, 2017) that reflective and impulsive cognitive styles have the same cognitive level in terms of geometry. The students with the reflective and impulsive cognitive styles are at the second level of cognitive level according to van Hiele's theory, namely being able to identify traits and determine the relationship between properties in geometry. This allows students to have the same thinking ability in statistics. Also, the results of research by (Nurdianasari et al., 2015) state that both reflective and impulsive cognitive styles have outstanding mathematical literacy skills in the aspects of representing data and using mathematical tools.

Reflective and impulsive cognitive styles differentiate students' ability to evaluate information critically in the aspect of statistical literacy. Research by (Amalia et al., 2020) shows that differences in cognitive styles also differ in statistical literacy abilities. This study (Amalia et al., 2020) is in line with the results of this study. Amalia's research was focused on students with field-dependent and a field-independent cognitive style while in this study was focused on reflective and impulsive cognitive styles. According to (Riding \& Cheema, 1991), students with a reflective cognitive style are more likely to be field independent than the student with the impulsive cognitive style. 
The differences between reflective and impulsive cognitive styles generally do not affect students' statistical literacy skills because the conclusions drawn were the same. The students' statistical literacy skills did not differ significantly. However, the student with the reflective cognitive style think more analytically and able to evaluate statistical information critically. The student with the reflective cognitive style was the same as the student with the impulsive cognitive style who tend to be holistic and unable to evaluate information critically. Students' statistical literacy skills and their cognitive styles did not affect decision-making in solving routine questions which only require general or holistic understanding. However, if they are faced with a problem that requires analytical processes, their cognitive styles may affect decisionmaking. This is consistent with research by (Azhil et al., 2017; Ulya, 2015) that students with the reflective cognitive style have different problem-solving abilities compared to the students with the impulsive cognitive style.

\section{Conclusion and Suggestion}

Students with reflective and impulsive cognitive styles possess statistical literacy skills in the form of the ability to interpret statistical information or data, understand statistical concepts, and represent statistical data into different forms. In evaluating information or arguments, the student with the reflective cognitive style tended to be more critical by basing each argument from the results of calculations analytically. The student with the reflective cognitive style tended to use analytical processes in drawing statistical conclusions. Meanwhile, the student with the impulsive cognitive style had less cognitive maturity and tended to use holistic processes rather than analytical in drawing statistical conclusions.

Based on the results of this study, it is suggested that in the learning process, students do not rush in answering a question or problem. Teachers need to keep reminding the students to review their answers so that the answers are based on valid and analytical arguments. Thus, the weakness of students with the impulsive cognitive style can be overcome. It is suggested to conduct in-depth studies on students' statistical literacy skills in solving higher-order thinking problems.

\section{References}

Amalia, F., Wildani, J., \& Rifa'i, M. (2020). Literasi Statistik Siswa Berdasarkan Gaya Kognitif Field Dependent dan Field Independent. Jurnal Edukasi Matematika Dan Sains, 8(1), 1. https://doi.org/10.25273/jems.v8i1.5626

Amimah, H. S., \& Fitriyani, H. (2017). Level Berpikir Siswa SMP Bergaya Kognitif Refleksif dan Impulsif Menurut Teori Van Hiele Pada Materi Segitiga. In Seminar Nasional Pendidikan, Sains dan Teknologi Fakultas Matematika dan Ilmu Pengetahuan Alam Universitas Muhammadiyah Semarang (pp. 133-138).

Aprilia, N. C., Sunardi, S., \& Trapsilasiwi, D. (2017). Proses Berpikir Siswa Gaya Kognitif Reflektif dan Impulsif dalam Memecahkan Masalah Matematika di Kelas VII SMPN 11 Jember. Jurnal Edukasi, 2(3), 31-37. https://doi.org/10.19184/jukasi.v2i3.6049

As'ari, A. R., Tohir, M., Valentino, E., Imron, Z., \& Taufiq, I. (2017). Matematika (Edisi Revi). Jakarta: Kementerian Pendidikan dan Kebudayaan.

Azhil, I. M., Ernawati, A., \& Lutfianto, M. (2017). Profil Pemecahan Masalah Matematika Siswa Ditinjau dari Gaya Kognitif Reflektif dan Impulsif. Jurnal Review Pembelajaran 
Matematika, 2(1), 60-68. https://doi.org/10.15642/jrpm.2017.2.1.60-68

Ben-zvi, D., \& Garfield, J. (2014). The Challenge of Developing Statistical Literacy, Reasoning and Thinking. In The Challenge of Developing Statistical Literacy, Reasoning and Thinking (pp. 3-15). https://doi.org/10.1007/1-4020-2278-6

Callingham, R., \& Watson, J. M. (2017). The development of statistical literacy at school. Statistics Education Research Journal, 16(1), 181-201.

Gal, I. (2002). Adults' Statistical Literacy: Meanings, Components, Responsibilities. International Statistical Review, 70(1), 43. https://doi.org/10.2307/1403719

Gravemeijer, K., Stephan, M., Julie, C., Lin, F., \& Ohtani, M. (2017). What Mathematics Education May Prepare Students for the Society of the Future? International Journal of Science and Mathematics Education, 15, 105-123. https://doi.org/10.1007/s10763-0179814-6

Hafiyusholeh, M. (2015). Literasi Statistik dan Urgensinya Bagi Siswa. Wahana, 64(1), 1-8.

Hartuti, P. M., \& Widyasari, H. (2016). Peran kemampuan Awal Matematika dan Persepsi Mahasiswa pada Statistika Terhadap Prestasi belajar Statistika. Jurnal SAP, 1(2), 135-144.

Hoyles, C., Wolf, A., Kent, P., \& Molyneux-Hodgson, S. (2002). Mathematical skills in the Workplace. Institute of Education, University of London. https://doi.org/10.11120/msor.2003.03010004a

Hoyles, Celia \& Noss, Richard \& Kent, Phillip \& Bakker, A. (2010). Improving mathematics at work: The need for techno-mathematical literacies. London: Routledge.

Maryati, I., \& Priatna, N. (2018). Analisis Kemampuan Literasi Statistis Siswa Madrasah Tsanawiyah dalam Materi Statistika. Journal of Medives: Journal of Mathematics Education IKIP Veteran Semarang, 2(2), 205-212. https://doi.org/10.31331/medives.v2i2.640

Miles, M. B., \& Huberman, M. (2007). Analisis Data Kualitatif. Jakarta: Penerbit Universitas Indonesia.

Mulya, N., Nurlaelah, E., \& Prabawanto, S. (2018). Students' statistical literacy on junior high school. In International Conference on Mathematics and Science Education of universitas Pendidikan Indonesia (Vol. 3, pp. 710-714).

Nishfani, N., Kusmanto, H., \& Akbar, R. O. (2017). Analisis Tingkat Kemampuan Literasi Statistik Siswa SMA Sederajat Berdasarkan Mutu Sekolah. In Prosiding PROCEDIAMATH (pp. 33-47).

Nurdianasari, H., Rochmad, R., \& Hartono, H. (2015). Kemampuan Literasi Matematika Siswa Kelas VIII Berdasarkan Gaya Kognitif. Unnes Journal of Research Mathematics Education, 4(2), 76-83.

Rahayu, Y. A., \& Winarso, W. (2018). Berpikir Kritis Siswa Dalam Penyelesaian Matematika Ditinjau Dari Perbedaan Tipe Gaya Kognitif Reflektif Dan Impulsif. Jurnal Imiah Pendidikan Dan Pembelajaran, 2(1). https://doi.org/10.23887/jipp.v2i1.13279

Riding, R., \& Cheema, I. (1991). Cognitive Styles-an overview and integration. Educational Psychology, 11(3-4), 193-215. 
Rochika, N. D., \& Cintamulya, I. (2017). Analisis Berpikir Kritis Siswa Bergaya Kognitif Reflektif dan Impulsif pada Pelajaran Biologi melalui Model Means Ends Analysis ( MEA ) Menggunakan Media Visual Analysis of Critis Thinking Reflectif and Impulsive Cognitive Style Students on Biology Learni. In Proceeding Biology Education Conference (Vol. 14, pp. 562-566).

Rozencwajg, P., \& Corroyer, D. (2005). Cognitive processes in the reflective-impulsive cognitive style. Journal of Genetic Psychology, 166(4), 451-463. https://doi.org/10.3200/GNTP.166.4.451-466

Shabani, S., Ramazani, M., \& Alipoor, I. (2017). The Effect of Impulsivity vs . Reflectivity on Reading Comprehension of Iranian EFL Learners. International Journal of Education \& Literacy Studies, 5(3), 52-56.

Sharma, S. (2017). Definitions and models of statistical literacy: a literature review. Open Review of Educational Research, 4(1), 118-133. https://doi.org/10.1080/23265507.2017.1354313

Sulisawati, D. N., Lutfiyah, L., \& Murtinasari, F. (2019). Difference of Mistakes ReflectiveImpulsive Students In Mathematical Problem Solving. International Journal of Trends in Mathematics Education Research, 2(2), 101. https://doi.org/10.33122/ijtmer.v2i2.115

Takaria, J., \& Talakua, M. (2018). Kemampuan Literasi Statistik Mahasiswa Calon Guru Ditinjau dari Kemampuan Awal Matematika. Jurnal Kependidikan, 2(2), 395-408.

Ulya, H. (2015). Hubungan Gaya Kognitif dengan kemampuan Pemecahan Masalah Matematika Siswa. Jurnal Konseling GUSJIGANG, 1(2).

Warli, W. (2010). Profil Kreativitas Siswa yang Bergaya Kognitif Reflektif dan Siswa yang Bergaya Kognitif Impulsif dalam Memecahkan Geometri. Universitas Negeri Surabaya.

Wing-yan, V. (2013). Promoting Statistical Literacy Among Students. In Proceedings of the Joint IASE/IAOS Satellite Conference (pp. 1-6). Macao. 